International Review of Research in Open and Distributed Learning Volume 16, Number 1

February - 2015

\title{
The Analysis of Iranian Students' Persistence in Online Education
}

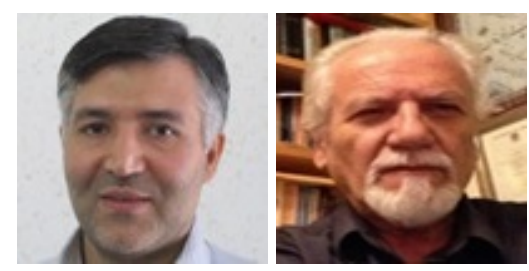

Mahdi Mahmodi and Issa Ebrahimzade

Payam Noor University, Iran, Islamic Republic of

\begin{abstract}
In the following research, the relationship between instructional interaction and student persistence in e-learning has been analyzed. In order to conduct a descriptive-analytic survey, 744 undergraduate e-students were selected by stratified random sampling method to examine not only the frequency and the methods of establishing an instructional interaction, but also the barriers to the student persistence in e-learning. The research findings confirmed the relationship between the instructors' and the students' application of two interaction methods including the discussion forum and email (asynchronous method), as well as the relationship between the frequency of instructional interaction and the student persistence in e-learning. According to the findings, family and job commitment, loss of instructional motivation and economic problems constitute the most important barriers to the student persistence in elearning. The research results can help reduce one of the primary concerns of online learning, that is the student persistence rate, if they would be implemented in various instructional systems such as higher instructional system, for the purpose of providing favorable condition in e-learning, facilitating online learning interactions and, eventually, increasing the student persistence in e-learning.
\end{abstract}

Keywords: e-learning; instructional interaction; synchronous communication; asynchronous communication; persistence 


\section{Introduction}

While the open and distance educational system emphasizes personal training and independent learning, new trends of education including online and e-learning introduce special environments in which separate, individual environments of open and distance institutions are replaced by interaction, group-communicate environments (Ebrahimzade, 2008, p. 5). However, dropout is mentioned as the primary barrier of e-learners' success in higher education, resulting in the students' failure in academic graduation. The studies revealed that online courses included a significantly higher dropout rate than in-person courses. Specifically, the dropout rate of online courses had been declared to be as high as a 40-50 percent rate, compared to the in-person courses' 10-20 percent dropout rate (Carter, 1996; Parker, 2003, p. 59). The results showed a clear relationship between the student's interaction with the instructor, as well as with other students and between the students' satisfaction with online courses and their own educational progress (Farahani, 2003, p. 10).

The specific research subject consists of two questions: First, is there any relationship between the student persistence, frequency and the method of establishing an instructional interaction? Second, what are the primary barriers to the student persistence in terms of three aspects of environment-related, learner-related and institution-related barriers?

\section{Types and Methods of Interaction}

Communication technologies have been implemented in educational systems in order to develop interactions between all participants during the training activities (Fahy, 2005). Instructional interaction is defined as a transaction between the learner and the instructor, for the purpose of accomplishing an instructional objective. This definition is consistent with the discussions that emphatically support the use of modern technologies and distance learning (Lulee, 2010, p. 13). Gunawardena, Lowe and Anderson (1997) have defined interaction as "a set of interconnected, bilaterally exchanged messages" (Sing \& Khine, 2006, p. 252). Ebrahimzade (2005), implying all basic elements of education, introduces three elements including the learner, the instructor and the content as the most important ones in education. He continues: "regardless which element is considered as the central element of educational system, learning - teaching process is the outcome of interaction between all three elements of instructor, learner and content" (p. 7).

Moore and Kearsley have mentioned three types of interaction influencing distance learning: learner-content, learner-instructor, learner-learner interaction (2011, p. 15). According to Moore, in a broad look, interaction involves all activities conducted during the teaching-learning process. Hillman, Willis, and Gunawardena (1994) argued that Moore's discussion of interaction was inadequate. They proposed a learner-interface interaction to address the interaction between learner and the electronic classroom (Lulee, 2010, p. 5). Sutton (2001) has introduced a fifth form of interaction called the successor interaction, according to which those learners deprived from direct interaction with the classmates would learn through observing and processing the

This work is licensed under a Creative Commons Attribution 4.0 International License. 
quality of interaction between other students, in other words, those other students interact on behalf of them ( p. 232).

Anderson (2003) rejects the fourth and the fifth types of interaction, arguing that all forms of interactions in distance education play the role of a mediator or arbitrator. Therefore, learnermediator interaction is approved as a common element in all three types of interaction. Likewise, successor interaction is the other type fulfilled only in combination with other forms of interaction and through active interaction with other participants. Hence, successor interaction is considered as another form of interactions, not as a separate concept. Anderson (2003) has presented three different types of interaction: instructor-instructor (between instructors), instructor-content (for the development and application of content-related objectives) and content-content interaction (referring to the intelligent programs or agents) (Lulee, 2010, p. 5). Figure 1 shows six types of instructional interactions, the primary three types of which had been firstly introduced by Moore (1989) and then extended by other experts such as Anderson and Garrison (1998).

\section{Student/Student}

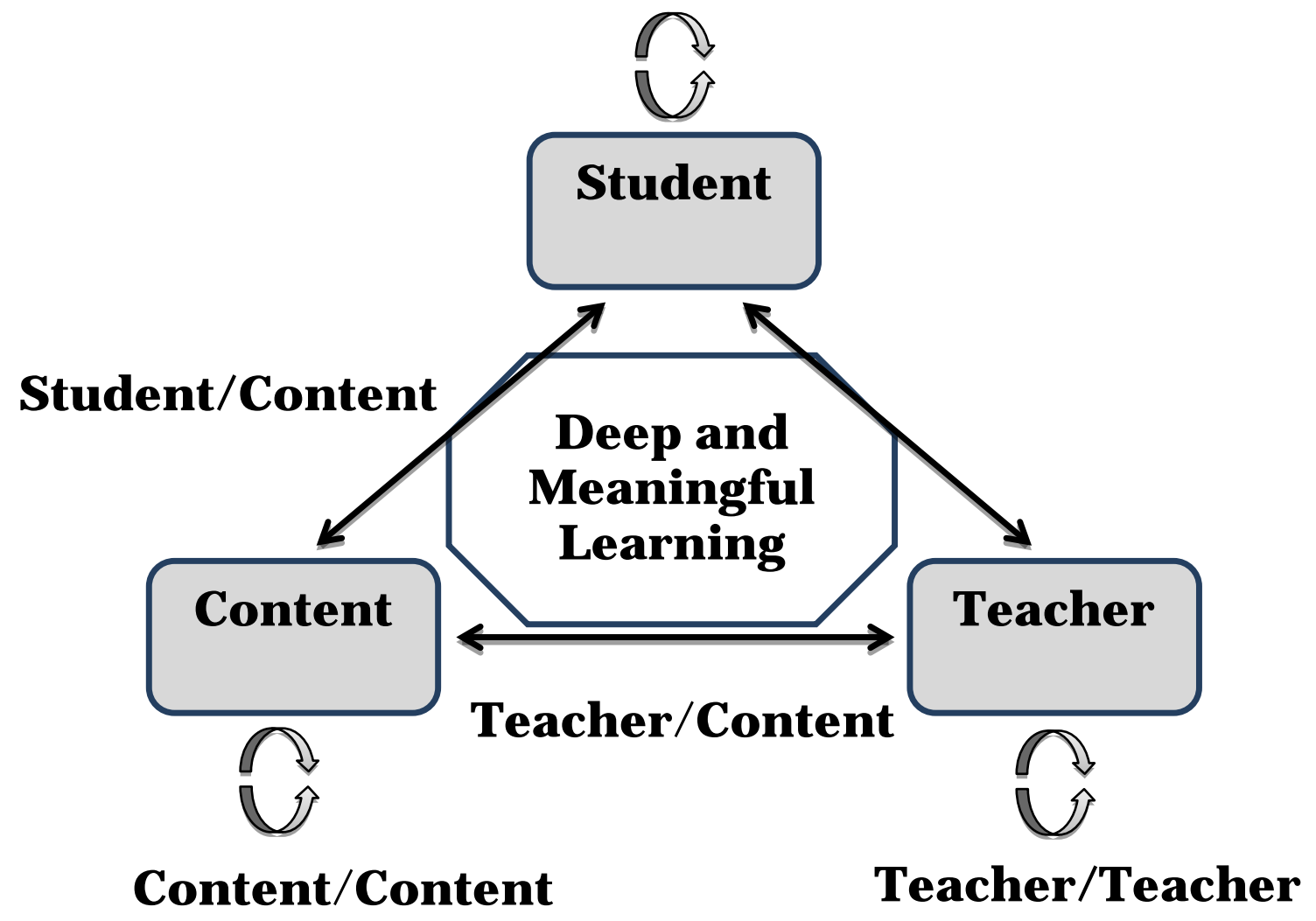

Figure 1. The interaction theory typology (Garrison \&Anderson, 2003, p.43). 
Regarding online communication methods, Kearsley remarks an important difference between the immediate (synchronous) and the delayed (asynchronous) interaction methods, influencing the quality feedback to the learner. Garrison (1987), Holmberg (1995), Smith, Dillon (1999) and others have considered feedback as a vital element of learning process (Kearsley, 2007). Distance learning technologies support the synchronous interactions that provide immediate feedbacks to the learners and motivate them (Moore \& Kearsley, 1995; Tello, 2002, p. 48).

Sutton introduces another framework in order to extensively define distance learning. He describes the features of distance education as an extended spectrum, at one end of which rests a type of distance education establishing an asynchronous and uncoordinated relationship between the learner and the instructor, also presenting a completely distant, single-media training without any kind of direct, face-to-face communication; yet, at the other end of spectrum, the synchronous education is fulfilled consistent with the learner-instructor needs, and applying multi-media facilities (Julien, 2006, p. 203). Both asynchronous (delayed) and synchronous (immediate) e-learning tools facilitate communications, conversations and discussions not only among students and instructors, but also among other students (Collison, Elbaum, Havind \& Tinker, 2000; Salmon, 2000). Asynchronous communication tools include email and discussion forum. They provide the learner and instructor with the facility of sending questions and notes, and others have the chance to answer in another time. Synchronous communication tools such as chat, video chat and audio conference require the learner and instructor to be online at the same time; they also provide the participants with the facility of feedback and immediate answer (Tello, 2002, p. 14).

\section{Interaction and Persistence}

The importance of instructor-learner interaction in producing positive educational results has been scientifically proved by document. Flanders (1990) conducted many studies on instructorlearner interaction in face-to-face classes and concluded that the increase of such interaction positively affected learners' progress and their attitude toward learning (Kuh \& $\mathrm{Hu}, 2001$ ). Pascarella and others, Pascarella and Chapman, (1993) also Terenzini (1976) have conducted extensive surveys on instructor-student interaction among undergraduate students. The results differentiated between formal (scientific) interactions taking place within the classroom and informal (social/recreational) ones occurring outside. During research, they concluded that the frequency and content of both formal and informal interactions between undergraduate students and instructors affect the students' progress (Kuh and Hu, 2001; Pascarella and Terenzini, 1993), the students' persistence (Terenzini and Pascarella, 1980), and completion of their college education for graduation (Tinto, 1987; Tello, 2002, p. 13). A significant volume of persistencerelated and dropout-related research literature is derived from a theory proposed by Vincent Tinto. Tinto provides a model for student dropout, according to which, persistence (the student's commitment to the completion of studying programs at a specific institution) results from the scientific and social integration of students as well as the community within the institution (Tinto, 1987). Pascarella and Chapman applied Tinto's model to the computer students and

This work is licensed under a Creative Commons Attribution 4.0 International License. 
concluded that scientific integration (formal interaction) affects the student persistence more seriously than social integration (informal interaction) (Svedberg, 2010, p. 19).

Since this research seeks to analyze the relationship between instructional interaction and student persistence, it is important to recognize a range of factors influencing this relationship and accordingly the students' decision about persistence. In this regard, Berge and Huang (2004) provided a dynamic and generalized model, the primary variables of which include personal, institutional and circumstantial factors (p. 102)

\section{The Research Purpose}

The researchers conducted a descriptive-analytic survey in order to study the relationship between the instructional interaction and the student persistence in e-learning. Here's the list of some specific questions having been answered by this research:

a) Is there any relationship between the frequency of instructional interaction and the student persistence in e-learning?

b) Is there a relationship between the instructional interaction method and the student persistence in e-learning?

c) What are the barriers to the student persistence in e-learning?

\section{Methodology}

\section{Participants}

The participants include 5,285 Iranian undergraduate students formally accepted from 2011 to 2013 to study in online courses of three colleges. In Table 1, the statistical population of the research called as "the number of participants" has been separately shown in ten online instructional courses, based on the college name. 
The Analysis of Iranian Students' Persistence in Online Education

Mahmodi and Ebrahimzade

Table 1

Statistical Population, Response and Persistence Rate of Each of the Online Courses

\begin{tabular}{|c|c|c|c|c|c|}
\hline \multirow[t]{2}{*}{ University } & \multirow[t]{2}{*}{ Course } & \multirow[t]{2}{*}{$\begin{array}{l}\text { Participants } \\
\text { number }\end{array}$} & \multicolumn{2}{|c|}{$\begin{array}{l}\text { Response } \\
\text { (Percent) }\end{array}$} & \multirow[t]{2}{*}{$\begin{array}{l}\text { Persistence } \\
\text { rate }\end{array}$} \\
\hline & & & $\begin{array}{l}\text { Persi } \\
\text { ster }\end{array}$ & $\begin{array}{l}\text { Non- } \\
\text { Persister }\end{array}$ & \\
\hline \multirow{4}{*}{$\begin{array}{l}\text { Khaje } \\
\text { Nasireddin } \\
\text { Tousi }\end{array}$} & Industrial Engineering & 207 & 22.4 & 15.2 & 0.78 \\
\hline & Information & 120 & 65.5 & 33.3 & 0.70 \\
\hline & $\begin{array}{l}\text { Technology } \\
\text { Enqineering }\end{array}$ & & & & \\
\hline & $\begin{array}{l}\text { Computer Engineering } \\
\text { (Software) }\end{array}$ & 120 & 56.5 & 45.7 & 0.71 \\
\hline \multirow{3}{*}{$\begin{array}{l}\text { Quran } \\
\text { sciences } \\
\text { and Hadith }\end{array}$} & Hadith Sciences & 606 & 27.8 & 48.9 & 0.92 \\
\hline & Quran Sciences & 771 & 10.6 & 21.2 & 0.93 \\
\hline & Information & 918 & 4.8 & 9.2 & 0.81 \\
\hline \multirow{5}{*}{ Shiraz } & Technology & & & & \\
\hline & $\begin{array}{l}\text { Computer Engineering } \\
\text { (Hardware) }\end{array}$ & 775 & 6.2 & 2.1 & 0.75 \\
\hline & $\begin{array}{l}\text { Computer Engineering } \\
\text { (Software) }\end{array}$ & 806 & 7.4 & 6.8 & 0.82 \\
\hline & Electrical Engineering & 125 & 65.6 & 26.9 & 0.79 \\
\hline & $\begin{array}{l}\text { (Telecom.) } \\
\text { Law }\end{array}$ & 837 & 8.4 & 16.8 & 0.87 \\
\hline \multicolumn{2}{|c|}{ Total (Mean) } & 5285 & 27.51 & 22.61 & 0.808 \\
\hline
\end{tabular}

\section{Sample Research}

Having determined 385 students as the research sample on the basis of statistical population and relevant formulas including Krejcie and Morgan's, researchers recognized to collect data from the three target colleges during e-students' final exams being held in-person on the campus to increase the external validity of the study, namely increase the results' generality. The researchers referred to the colleges during the examinations for several consecutive days, distributed the questionnaires among persistent students and collected the completed questionnaires. They also corresponded and communicated with non-persistent students through emails or phone calls for several times to receive their information and viewpoints. Accordingly, the actual research sample of the study was determined to be 744 students, including two groups of persistent and non-persistent students from three target colleges, equal to $14 \%$ of the whole studied population and two times more than the nominal case study.

\section{Response Rate to the Research Tools}

Since the course of study was considered as the data analysis unit of the research, the researchers tried to collect course-related data including the number of registrations, as well as the number 
of persistent and non-persistent students for three years of 2011, 2012 and 2013. According to the data collected from target colleges, we distributed questionnaires between persistent and nonpersistent students in such a way that each course would include an appropriate response rate. The response rate of each of the e-courses has been shown separately in the persistent and nonpersistent groups in Table 1.

It is noted that the rate of response in the traditional methods of sending out questionnaires, like personally interviewing the respondents, distributing and receiving of the questionnaires by hand or mailing is higher than the dispatch methods through internet and email. In this regard, Schillewaert, Langerak and Duhamel (1998) announced the response rate of three times of sending questionnaires by email to be between $22 \%$ - 36\% of the whole questionnaires (p. 316).

\section{Research Tools}

Research tools included two types of persistent and non-persistent questionnaires containing several personal questions, as well as 26 other questions having been developed by the use of relevant research tools. After the first collection of the two questionnaires, in order to provide validity, judgment method was used through which instruments themselves will be judged or refereed. For that purpose, the first copy of the questionnaires was handed to professors and university lecturers who are active in e-learning, and their opinions regarding each one of the questions were collected and analyzed. Then, according to their input, the questionnaires were amended. Finally, the questionnaires were approved by the intended professors and lecturers.

We also applied Cronbach's alpha coefficient to estimate the internal consistency of the measurement tools and eventually determine the reliability of the questionnaires. The SPSS v.18 software was applied to measure the internal consistency of the tools, and the results equaled 0.79 and 0.82 , shown sequentially for persistent and non-persistent students' questionnaires as an indicative of the tools' favorable validity.

\section{Determination of Persistence Rate}

Persistence rate considered as the dependent variable in this research refers to the students' commitment to a specific institution, completing the online training courses. Equation 1 was used to determine the rate of persistency related to each online course of study. First, the total number of formal and informal dropouts was subtracted from all the enrollments in that course so that the number of persistent students was obtained for that course. After that, the amount was divided by the total number of enrolled to specify the rate of students' persistency.

\section{Equation 1:}

Persistence rate $=$

the number of persistent students in each course (in total three years) the total number of registrations in that course

This work is licensed under a Creative Commons Attribution 4.0 International License. 
The persistence rate of each online course of study has been shown in Table 1 separately for each of the three colleges.

\section{Findings}

\section{Frequency of Interaction and Persistence}

First, the frequency and the average instructional interactions for ten online courses were determined as an exploratory analysis to identify the research data and study the relationship between all instructional interaction types.

The results marked no specific relationship between all interaction types except a positive and significant relationship between interaction type I (instructor-learner) and type II (learnerlearner) with the confidence level of $99 \%,(r=0.815, \mathrm{p}<0.01)$. Such a significant relationship revealed that an interaction index can be determined for each of the online courses based on the minimum frequency to be applied as a basis for subsequent calculations. As long as the aim of first question of research is recognizing the frequency relationship of instructional interaction with students' persistency in e-learning, the frequency of all of the six different interactions from instructional methods will be calculated for each online course of study and its average will be determined as an interaction index of that specific course.

At the end, correlation analysis was reformed to identify the relationship between the six types of instructional interactions, as well as the interaction index affected by the total frequency of them and the persistence rate, to answer the first question of the research, whether there is any relationship between the instructional interaction frequency and the student persistence in elearning and the results have been given in Table 2 .

Table 2

Correlation Coefficient Between Six Types of Instructional Interactions, Interaction Index and the Rate of Persistence

\begin{tabular}{|c|c|c|c|c|c|c|c|}
\hline & Persistence & $\begin{array}{l}\text { Inter- } \\
\text { action } \\
\text { I } \\
\end{array}$ & $\begin{array}{l}\text { Inter- } \\
\text { action } \\
\text { II }\end{array}$ & $\begin{array}{l}\text { Inter- } \\
\text { action } \\
\text { III }\end{array}$ & $\begin{array}{l}\text { Inter- } \\
\text { action } \\
\text { IV }\end{array}$ & $\begin{array}{l}\text { Inter- } \\
\text { action } \\
\mathrm{V}\end{array}$ & $\begin{array}{l}\text { Inter- } \\
\text { action } \\
\text { VI }\end{array}$ \\
\hline Persistence & 1 & $0.757^{*}$ & 0.537 & 0.206 & -0.194 & -0.536 & 0.152 \\
\hline $\begin{array}{l}\text { Interaction } \\
\text { Index }\end{array}$ & 0.508 & $0.917^{* *}$ & $0.832^{*}$ & 0.443 & 0.427 & 0.251 & 0.401 \\
\hline
\end{tabular}

This work is licensed under a $\underline{\text { Creative Commons Attribution } 4.0 \text { International License. }}$ 
As shown in Table 2 there is a positive, direct and significant relationship between the frequency of interaction type I (learner-instructor) and the student persistence in e-learning ( $r=0.757$, $\mathrm{p}<0.05$ ), but no significant relationship was detected between other five types of instructional interactions and persistence in e-learning. Also, the relationship between the interaction type I and II with the interaction index (with 99\% confidence) acknowledges the index as a representative of the instructional interaction frequency of each online course. Totally, the correlation coefficient between the instructional interaction index, as the statistical representative of total six types of instructional interactions and persistence, revealed no relationship between the frequency of instructional interaction and student persistence in elearning.

Since many students had problems with those questions concerning the frequency of instructional interaction and expressed their ignorance of the relationship between the instructor and colleagues (instructor-instructor) or between the instructor and content, and due to the high potential errors in the students' answers to these questions, the interaction frequency index was determined in the next stage, based on four types of interactions including: learner-instructor, learner-learner, learner-content and content-content. In other words, in this stage the students' answers to those questions concerning the instructor-instructor and instructor-content relationship were eliminated and replaced by the modified interaction frequency index. The result of the correlation analysis has been shown in Table 3.

Table 3

Correlation Coefficient Between the Modified Interaction Frequency Index and Persistence

\begin{tabular}{l|lll}
\hline & Persistence & $\begin{array}{l}\text { Interaction } \\
\text { (Modified) }\end{array}$ & Index \\
\hline Persistence & 1 & $0.650^{*}$ & \\
\hline
\end{tabular}

As shown in Table 3, the elimination of two questions concerning the instructor-instructor and instructor-content created a significant relationship between the frequency of instructional interaction and student persistence in e-learning $(r=0.650, n=10, p<0.05)$.

\section{Method of Interaction and Persistence}

First, we determined the frequency and the average application of the three e-communication methods including chat, discussion forum and email by the instructor and the student as well as the application period of each method by the student, so that the indices related to the three interaction methods would be designed and applied for the recognition of the relationship

This work is licensed under a Creative Commons Attribution 4.0 International License. 
between the interaction method and persistence. The values of the three indices of interaction methods, that is, chat, discussion forum and email indices, have been listed for each of the ten online courses in Table 4. In fact, each amount equal to the average of sum is related to the amount of professor to student's use and the amount of time student spent with online interaction methods in that online educational course.

Table 4

Values of the Three Interaction Method Indices

\begin{tabular}{l|lccc}
\hline & E-Course & $\begin{array}{c}\text { Chat } \\
\text { Index }\end{array}$ & $\begin{array}{c}\text { Discussion } \\
\text { Forum Index }\end{array}$ & $\begin{array}{c}\text { E-Mail } \\
\text { Index }\end{array}$ \\
\hline 1 & Industrial Engineering & 2.09 & 1.71 & 1.56 \\
2 & Information Technology & 2.23 & 1.85 & 1.86 \\
3 & $\begin{array}{l}\text { Engineering } \\
\text { Computer Engineering }\end{array}$ & 2.34 & 1.92 & 1.82 \\
& $\begin{array}{l}\text { (Software) } \\
4\end{array}$ & 1.69 & 1.83 & 2.00 \\
6 & Hadith Science & 1.80 & 1.94 & 2.27 \\
6 & Quran Science & 2.17 & 1.46 & 1.75 \\
7 & Information Technology & 1.84 & 1.11 & 1.97 \\
8 & $\begin{array}{l}\text { Compineering } \\
\text { (Hardware) }\end{array}$ & 1.76 & 1.20 & 1.72 \\
9 & Computer Engineering & 1.87 & 1.25 & 1.94 \\
1 & (Software) & & & 2.02 \\
0 & (Tectrical Engineering & 1.91 & 1.31 & \\
\hline
\end{tabular}

The difference between the interaction methods had been studied in order to identify the differences between the three indices of interaction method data, and the results have been listed in Table 5. Identifying such differences helps us recognize the students' methods of most interest. 
Table 5

Differences Between the Three Indices of Interaction Methods

\begin{tabular}{|c|c|c|c|c|c|c|c|}
\hline & Mean & $\begin{array}{l}\text { Std. } \\
\text { Deviatio } \\
\mathrm{n}\end{array}$ & $\begin{array}{l}\text { Std. } \\
\text { Error } \\
\text { Mean }\end{array}$ & $\mathrm{t}$ & $\mathrm{df}$ & $\begin{array}{l}\text { Sig. } \\
(2- \\
\text { tailed) }\end{array}$ & $\begin{array}{l}\text { Resul } \\
\mathrm{t}\end{array}$ \\
\hline $\begin{array}{l}\text { Chat and } \\
\text { Discussion } \\
\text { Forum Indexes }\end{array}$ & 0.414 & 0.318 & 0.101 & 4.111 & 9 & 0.003 & $\begin{array}{l}p<0.0 \\
5\end{array}$ \\
\hline $\begin{array}{l}\text { Chat and E- } \\
\text { Mail Indexes }\end{array}$ & 0.081 & 0.359 & 0.114 & 0.717 & 9 & 0.492 & $\begin{array}{l}p>0.0 \\
5\end{array}$ \\
\hline $\begin{array}{l}\text { Discussion } \\
\text { Forum and E- } \\
\text { mail Indexes }\end{array}$ & $\overline{0}-332$ & 0.357 & 0.113 & $\begin{array}{l}- \\
2.94 \\
2\end{array}$ & 9 & 0.016 & $\begin{array}{l}\mathrm{p}<0.0 \\
5\end{array}$ \\
\hline
\end{tabular}

Table 5 shows a significant difference between chat index and discussion forum index, as well as between the discussion forum index and email index; yet, no significant difference was found between discussion forum and email indices.

Eventually, correlation analysis was performed using Pearson correlation coefficient, the results of which are shown in Table 6, in order to study the relationship between each of the three indices of interaction methods and the student persistence in e-learning,

Table 6

Correlation Coefficient Between the Instructional Interaction Methods and the Persistence

\begin{tabular}{l|lll}
\hline & $\begin{array}{l}\text { Chat } \\
\text { index }\end{array}$ & $\begin{array}{l}\text { Discussion } \\
\text { forum Index }\end{array}$ & $\begin{array}{l}\text { E-mail } \\
\text { index }\end{array}$ \\
\hline & $-.649^{*}$ & .091 & .502 \\
Persistence & & & \\
\hline
\end{tabular}

As shown in Table 6, there is a significant but inverse relationship between chat index and student persistence at the confidence level of $95 \%$. Yet, no significant relationship was recognized between chat and email indices and student persistence. 


\section{Further Reviews}

Since neither the instructor-student nor the student-student relationships in e-learning are limited to the three methods of chat, discussion forum or email, and also as both the instructor and the students apply a combination of three mentioned methods of communication during the online training course, it is necessary to more precisely analyze the relationship between the primary e-communication method and its persistence rate. The question raised here whether there is any specific relationship between a certain combination of e-communication methods and the student persistence.

In search of the answer, two categorical variables including the primary method of instructor interaction and the primary method of student interaction were designed. In other words, the median helped determine the most applied online communication method by the instructors or the students in each online course. The median was selected in this stage, since in asymmetric distribution it is less influenced by the scores on the two sides of the curve than the mean is. Category types were determined on the basis of the data obtained by the communication methods in the questionnaire including chat, email, the combination of two methods and also all methods together. Discussion forum or its combination with another method was excluded since this method had not been applied more than other methods in any of the online courses. Figure 2 describes the percentage distribution of ten online courses according to the primary method of instructor interaction.

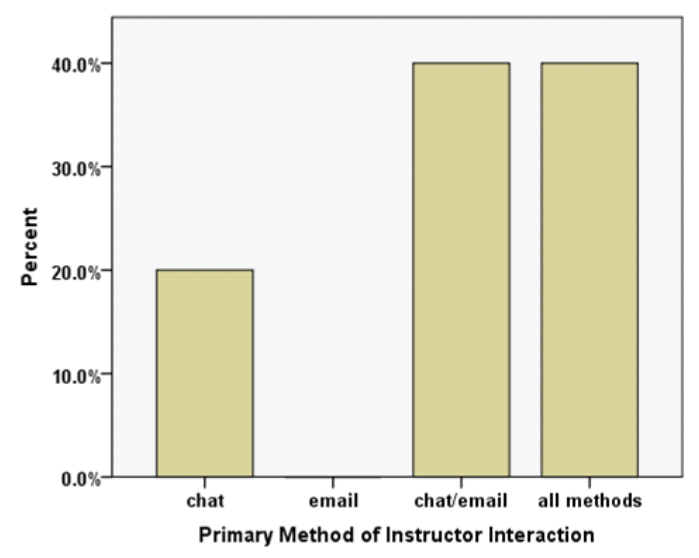

Figure 2. Distribution of ten online courses based on the primary method of instructor interaction.

As the figure shows, the combination of chat and email methods establishes the primary method of instructor interaction in $40 \%$ of online courses (four courses). In another $40 \%$ of courses, the instructor applied all online communication methods equally, and in the remaining $20 \%$ of the courses (two courses), chatting was the primary method of communication with the instructor. 
In Figure 3, the percentage distribution of ten online courses is shown according to the primary method of student interaction.

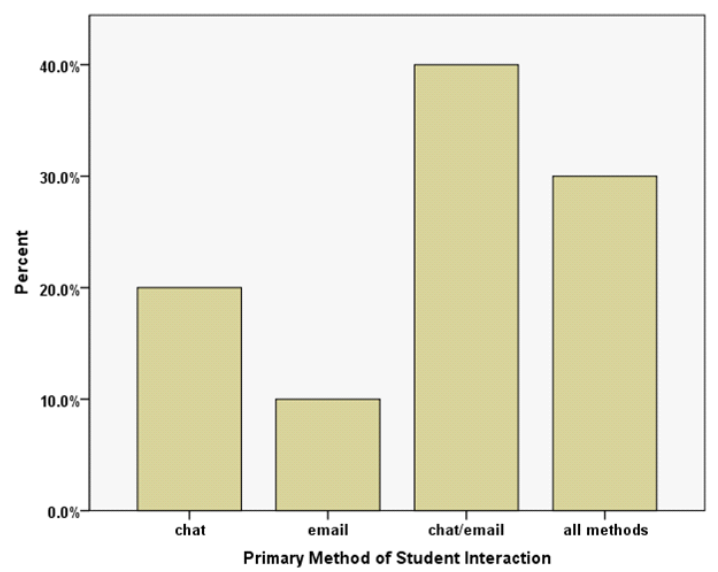

Figure 3. Distribution of ten online courses based on the primary method of student interaction.

As Figure 3 shows, the primary method of students interaction in $40 \%$ of online courses (four courses) is a combination of chat and email. This is important because according to Figure 2, in $40 \%$ of online courses, the primary method of instructor interaction includes the same combination. Also, in $30 \%$ of online courses, all methods of online communication have been equally applied by the students.

The significant or insignificant nature of the persistence rate of online courses in this research, according to the primary method of instructor or student interaction, was determined with ANOVA test, in such a way that the primary method of instructor or student interaction was regarded as the independent variable with four categories, versus the persistence rate as the dependent variable. The results of both analyses have been listed in Tables 7 and 8 .

\section{Table 7}

One-Way Analysis To Examine the Differences Between Persistence Rates (Based on the Primary Method of Instructor Interaction)

\begin{tabular}{l|lllll}
\hline & SS & df & MS & F & $\begin{array}{l}\text { P-Value } \\
\text { (Sig.) }\end{array}$ \\
\hline $\begin{array}{l}\text { Between } \\
\text { Groups }\end{array}$ & 0.004 & 2 & 0.002 & 0.255 & 0.782 \\
Within & 0.054 & 7 & 0.008 & & \\
Group & & & & & \\
Total & 0.058 & 9 & & & \\
\hline
\end{tabular}

$F_{(2,7)}=0.255 ; P>0.05$ 
As the research results on the difference between the persistence rates of online courses reveals in Table 7 and according to the categories related to the primary method of instructor interaction, that is, chat, email, a combination of both and a combination of all methods, there is no significant difference between the persistence rates of online courses on the basis of categories related to the primary method of instructor interaction. In other words, null hypothesis, claiming no difference between persistence rates of online courses on the basis of categories related to the primary method of interaction with the teacher, has been approved.

Table 8

One-Way Analysis To Examine the Difference Between Persistence Rates (Based on the Primary Method of Student Interaction)

\begin{tabular}{l|lllll}
\hline & SS & df & MS & F & $\begin{array}{l}\text { P-Value } \\
\text { (Sig.) }\end{array}$ \\
\hline $\begin{array}{l}\text { Between } \\
\text { Groups }\end{array}$ & 0.034 & 3 & 0.011 & 2.953 & 0.120 \\
$\begin{array}{l}\text { Within } \\
\text { Group }\end{array}$ & 0.023 & 6 & 0.004 & & \\
Total & 0.058 & 9 & & & \\
\hline
\end{tabular}

$F_{(3,6)}=2.953 ; P>0.05$

Furthermore, the results of examining the difference between persistence rates of online courses on the basis of categories related to the primary method of student interaction in Table 8 shows that there is no significant relationship between the persistence rates of online courses on the basis of the primary method of student interaction. In other words, null hypothesis, claiming no difference between the persistence rates of online courses on the basis of the primary method of student interaction, has been approved.

\section{Barriers of Persistence}

As mentioned, the variables that educational institutes can exploit to increase a learner's persistency are divided into three groups which are personal, institutional and circumstantial variables. Towards this goal along with more correspondence with e-learning conditions, three groups of persistence barriers including learner-related, institution-related and environmentrelated were examined. Several questions relevant to each of three barrier groups have been raised in the dropout (non-persistent) students' questionnaire. The percentage and the type of dropouts' answers about each of the questions have been shown in Figure 4.

This work is licensed under a Creative Commons Attribution 4.0 International License. 


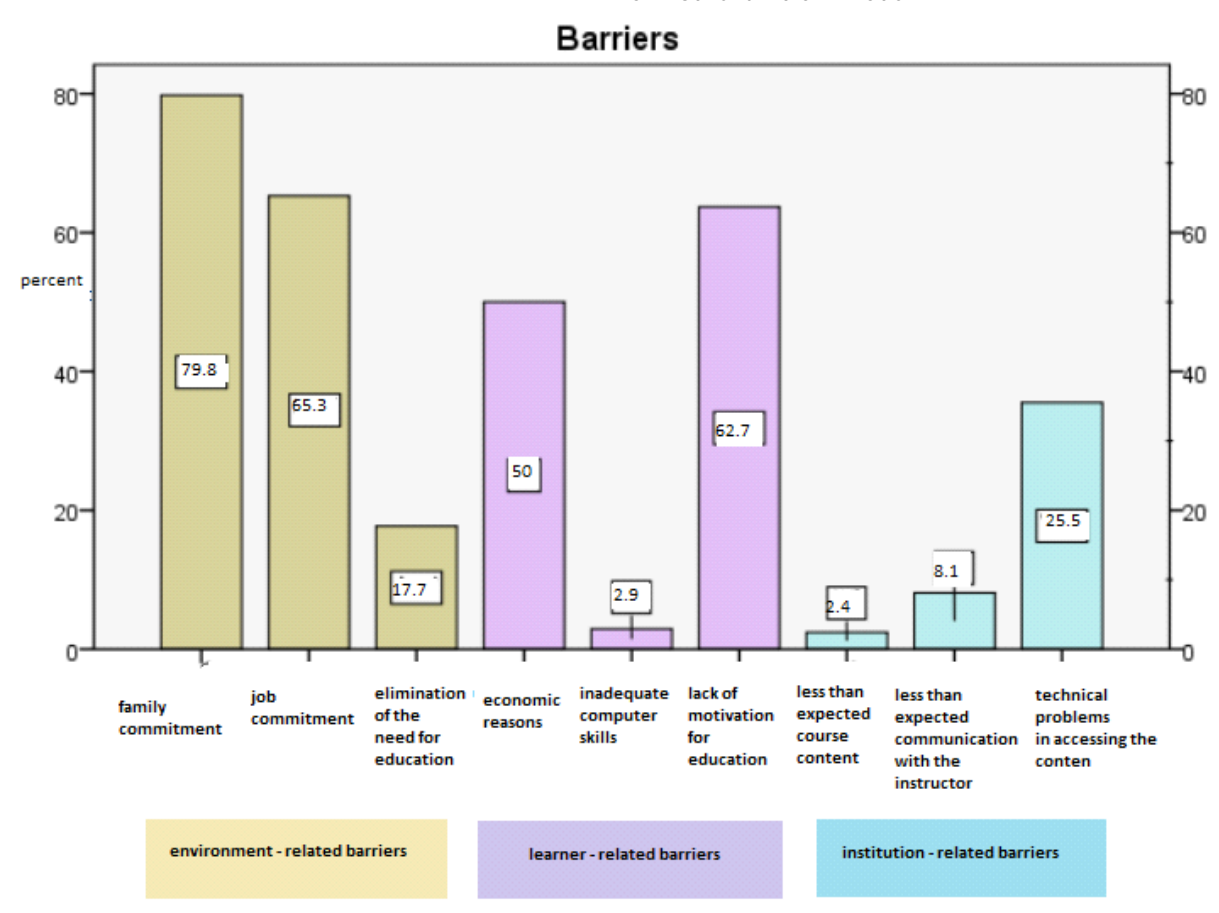

Figure 4. Percentage of non-persistent students' answers to each of the questions concerning barriers to persistence.

Regarding environment-related barriers, as Figure 4 shows, $79.9 \%$ of non-persistent students declared the family commitment, $65.3 \%$, with a little difference, the job commitment, and lastly just $17.7 \%$ the elimination of need for education as the reason of dropout.

Regarding learner-related barriers, Figure 4 shows that $50 \%$ of non-persistent students declared economic barriers, $2.9 \%$ the inadequate computer skills (in other words $97.1 \%$ claimed possessing sufficient computer skills necessary for education), and eventually $63.7 \%$ the loss of motivation to education as the reason of dropout.

Regarding institution-related barriers, as Figure 4 shows, only $2.4 \%$ of non-persistent students declared the unsatisfied expectations (in other words $97.6 \%$ were satisfied with the online training content), $8.1 \%$ the unsatisfactory communication with the instructor, and at last 35.5\% the technical problems in accessing online content as the reason of dropout. 


\section{Further Review}

Logistic regression test was applied in order to predict the potential relationship between six variables including sex, marital status, having a less than 18-year-old child, place to connect to the internet (home, office, café net), type of occupation (self-employed, civil service, unemployed), role in life (student, parent, employee) and persistence and the synchronous effect of those variables on persistence. In this regard, null hypothesis to be examined here indicated: "There is no relationship between each of the six variables and persistence" $\left(\mathrm{H}_{0}: \mathrm{b}=0\right)$

Table 9

Logistic Regression Results To Predict Potential Relationship Between Confounding Variables and Persistence

\begin{tabular}{|c|c|c|c|c|}
\hline & \multirow[t]{2}{*}{$\mathrm{df}$} & \multirow[t]{2}{*}{ Sig } & \multicolumn{2}{|c|}{$\begin{array}{lll}95 \% & \text { C.I. } & \text { for } \\
\operatorname{EXP}(B) & & \end{array}$} \\
\hline & & & Lower & Upper \\
\hline Sex & 1 & .001 & 1.486 & 4.982 \\
\hline Marital status & 1 & .000 & .001 & .083 \\
\hline $\begin{array}{l}\text { Having a less } \\
\text { than 18-year- } \\
\text { old child }\end{array}$ & 1 & .051 & .263 & 1.003 \\
\hline $\begin{array}{l}\text { Occupation } \\
\text { type }\end{array}$ & 2 & .016 & & \\
\hline Role in life & 3 & .001 & & \\
\hline $\begin{array}{l}\text { Place to } \\
\text { connect to the } \\
\text { internet }\end{array}$ & 3 & 148 & & \\
\hline Constant & 1 & .999 & & \\
\hline
\end{tabular}

Table 9 shows the status of six independent variables entered into the regression model. It is worth mentioning that since the three variables of "occupation type", "role in life" and "place to connect to the internet" comprise of more than two levels, they have changed to dummy variables based on the number of levels; and according to their calculation the overall effect has changed to the primary variable.

Due to the significance values obtained for each of the variables and also the constant value of model, null hypothesis regarding the four variables of "sex", "marital status", "type of occupation" and "the role in life" has been rejected with 95\% confidence $(\mathrm{p}<0.05)$. This certifies a kind of relationship between these four independent variables and persistence. Yet, the effect of two other variables, that is, "having a less that 18-year-old child" and "place to connect to the internet" on persistence is so small that it's rather negligible. 


\section{Discussion and Conclusion}

The capacity of online education to support, reinforce and increase the relationship between learners is considered as an advantage that helps provide a kind of collaborative learning environment (Tello, 2002; Dede, 2000; Kearsley \& Niederman, 1999). Although studying the relationship between the instructional interaction frequency index and the student persistence in e-learning identified no significant relationship (according to Table 2) and the results of some researches carried out by Tello (2002) acknowledge that, in order to enhance the research validity, the modified interaction index representing the frequency of four interactions (except instructor-instructor and instructor-content interaction) was applied, the results shown in Table 3 certifies a relationship between the frequency of instructional interaction and student persistence $(\mathrm{p}<0.05)$.

The research history indicates that some other researches including Pascarella and Chapman's studies support the findings. They extensively studied the instructor-student interaction among undergraduate students of in-person colleges and proved a relationship between the frequency and content of formal (scientific) as well as informal (social/recreational) interactions among instructors and B.A. students and their persistence in e-learning. Also, Towles, Ellis and Spencer (1993) concluded that the instructors' phone call with those learners attending distance video learning courses and perseverance in keeping in touch with them positively affects persistence rate of freshmen.

The other finding of this research determined a positive, direct and significant relationship between the instructional interaction type I (learner-instructor interaction) and students' persistence in e-learning $(\mathrm{p}<0.05)$. It is worth mentioning that Flanders (1990), studying instructor-learner interaction in face-to-face classes, concluded that the increase of this type of interaction positively affects the learners' progress and their attitude toward learning. In addition, Sweet (1986) examined the persistency of B.A. students attending correspondence course and concluded that the students' phone contact with the instructor has a positive relationship with the student persistence. Brown and Robinson (1997) claimed that instructional arrangements, students' instructional performance and their interaction with the instructors and college staff could differentiate between the students in case of persistence or dropout. The other finding of this survey was the relationship between the student-instructor interaction and student-student interaction in e-learning environment ( $p<0.01$ ). In other words, by the increase of student-instructor interaction, the interaction between the students increases as well. This is not such a notable finding, since against the primary role of the learner in online learning, the instructor's active role in online training environment has been proved to increase students' communication with each other and eventually help provide a collaborative learning environment.

Three indices of communication tools, that is, chat (synchronous method), discussion forum and email (asynchronous method) were applied to study the relationship between instructional 
interaction method and student persistence in e-learning.

The comparison between the frequency and the duration of each communication tool's application by the students proved a significant difference between the use of discussion forum and the use of chat, also between the use of discussion forum and email with $95 \%$ confidence. It means that some interaction methods had been more attractive to the users and more applied than other methods.

Studying the relationship between the three instructional interaction methods and student persistence determined no positive, direct and significant relationship between them. Following further investigations, since a combination of methods would be used instead of one single method, two new variables called the primary method of instructor interaction and the primary method of student interaction categorized as chat, email, the combination of chat and email and all methods together were introduced. The results revealed that in $40 \%$ of online courses, the primary method of instructor interaction included a combination of chat and email. Similarly, in other $40 \%$ of online courses, the primary method of student interaction included a combination of the same methods. This result is important for several reasons: First, the application of a single method or a combination of two or more methods by the instructor increased the students' application of that specific method or their combination to communicate with the instructor and other students; second, among various tools of e-communication methods, the instructors and the students mostly tend to take advantage of chat and email.

Performing ANOVA test, the researchers could examine whether according to the primary method of instructor or student interaction, the difference between the persistence rates of online methods was significant or insignificant, and the final result showed no significant relationship between the persistence rates of online methods based on the categories of the primary method of instructor or the student interaction. In other words, the application of a specific method or a combination of methods could make no difference in persistence rate.

Questions concerning the three groups of barriers including environment-related, learner-related and institution-related barriers have been contained in dropout students' questionnaire.

Family commitment was acknowledged as the primary reason for dropout of $79.8 \%$ of students. In this regard, Bean and Metzner (1985) introduced a model of four factors including scientific, predisposing, environment-related and social integration-related variables effective on persistence. In this model family commitment is recognized as an environment-related variable. Furthermore, the research results show that in $65.3 \%$ of dropouts, job commitment played as the determining factor. In this regard, Tello (2002), having carried out several researches on student persistence in e-learning, claimed that one third of the students declared job commitments as the reason of dropout. He found those results compatible with the previous research results (Fjortoft, 1995; Kerka, 1995; Lu, 1997; Pappas \& Loring, 1985).

Concerning learner-related barriers, $63.7 \%$ of non-persistent students considered lack of 
motivation for education as a reason of dropout. Similarly, Frankola (2001) identified seven factors effective on the dropout of those students, who possessed a legal entity in corporations, the most important of which is the lack of motivation for education (Frankola, 2001, p. 56). In addition, $50 \%$ of non-persistent students announced economic reasons for dropout. In this regard, the research of Maurice, Wu and Finnegan (2005) determined that financial support for online students is one of the main factors predicting whether an online course will be completed or left incomplete.

About institution-related barriers, reviewing the results of non-persistent students' answers revealed that $35.5 \%$ of dropouts claimed frequent technical problems in accessing the online instructional contents and eventually, only $8.1 \%$ of dropouts expressed dissatisfaction about the ease of communication with the instructor. In other words, most of them were pleased with the level of their online communication with the instructor. In this regard, Tello research results proposed that equal number of persistent or non-persistent students (almost 11\%) declared their dissatisfaction of communication with the instructor as the reason to give up online education or refuse to register for the next term.

Further studies on recognizing barriers to student persistence in e-learning provided useful results with the emphasis on demographics. In this regard, logistic regression test was conducted to predict a potential relationship between confounding variables ("sex", "marital status", "having less than 18-year-old child", "type of occupation", "role in life" and "place of connection to the internet"), student persistence and their asynchronous effect on persistence. The results revealed a positive and significant relationship between sex and persistence with 95\% confidence. Descriptive analysis of two groups of persistent and non-persistent students in terms of sex emphasized the significance of this variable in student persistence. According to the results of the analysis, $55 \%$ of students in persistent group were women and $45 \%$ were men. Yet, in nonpersistent group $60.5 \%$ of dropouts were men. Some studies including Berge and Huang (2004), relying on the data exchange consortium, report on student persistence (2001), in which the rates of persistence and dropout for women have been declared to be constantly higher than men, support this finding. Also, Peckham and colleagues concluded that the percentage of male dropouts is higher than females, in such a way that $70 \%$ of dropouts were men and the rest were women.

The examination of the marital status and students' persistency in e-learning indicates that there is a $95 \%$ of confidence between the two relations. Also, a descriptive analysis of persistent and non-persistent students from the point of view of marital status demonstrates that in persistent group, 52\% were married and $48 \%$ were single and in non-persistent group, $82 \%$ were married and $18 \%$ were single. In other words, a significant percent of non-persistent was composed of married people. In this relation, some studies could be found that emphasize the importance of being married and the responsibility a person holds as a result of it, as well as the relation it can have with students' persistency. For example, Bean and Metzer (1985), Rovai (2003) and Tello (2002) highlighted the importance of individual's responsibility on family and its relation to

This work is licensed under a Creative Commons Attribution 4.0 International License. 
persistency in education.

Studying the relationship between the role in life and students' persistence in e-learning certified a positive and significant relationship with $95 \%$ confidence. Furthermore, descriptive analysis of both groups in terms of the role in life showed that $54 \%$ of non-persistent students considered their parental role as their primary role in life; while, just $23 \%$ of persistent students had basically such a role. In studies by some researchers including Bean and Metzner (1985) and Rovay (2003) on the importance of the online learner's role in life specifically the parental role followed by family commitment, the individual's responsibility for family is introduced as an effective factor on student persistence in e-learning. Also, Tello (2002) introduces the flexibility in terms of time and place of access to the course content as a privilege for those online learners who are committed to their role in family life.

Among other findings, necessary to be taken into serious consideration by instructional planners, is the comparison between both groups in terms of age. This finding revealed that relatively, the average age of students in non-persistent group (a total of 124 students, average age 33.3) is higher than the persistent group (a total of 595 students, average age 29.3); so, it is concluded that the younger the students, the more adaptability with the e-learning conditions.

The results of comparison between $46 \%$ of non-persistent students and 41.4 persistent students' previous field of study, who had the background of studying in the traditional college education system, revealed increased likelihood of dropout among the students with the instructional background in theoretical courses such as literature and human sciences, theology and Islamic studies than dropout in technical courses. While, 1.8\% of students in persistent group declared theology and Islamic studies as their previous field of study, this figure was $21.8 \%$ in the nonpersistent group. Although, $22 \%$ of persistent students declared technical and engineering courses as their previous major, this figure was just $1.6 \%$ for the non-persistent group. Therefore, it is concluded that the students with higher computer knowledge, due to their previous instructional field, are more capable of pursuing online courses and prove to be more persistent in e-learning than other students.

This work is licensed under a $\underline{\text { Creative Commons Attribution } 4.0 \text { International License. }}$ 


\section{References}

Berge, Z., \& Huang, Y. (2004). A model for sustainable student retention: A holistic perspective on the student dropout problem with special attention to e-learning. Distance Online Symposium, The American Center for the Study of Distance Education, 13(5). 97-108. Retrieved from http:// /earningdesign.psu.edu/deos/deosnews13_5.pdf

Carter, V. (1996). Do media influence learning? Revisiting the debate in the context of distance education. Open Learning, 11(1), 31-40.

Collison, G., Elbaum, B., Haavind, S., \&Tinker, R. (2000). Facilitating online learning: Effective strategies for moderators. Madison: Atwood Publishing.

Ebrahimzade, I. (2008). Pedagogy based on information technology: Conceptual query. J ournal of Paik Noor, 4(4), 4-13.

Ebrahimzade, I. (2005). Teaching- learning process and open universities. J ournal of Paik Noor, 1(2), 4-11.

Fahy, P. (2005). Online and face-to-face group interaction processes compared using Bales' interaction process analysis (IPA). European J ournal of Open, Distance and ELearning, 1. Retrieved from http:// www.eurodl.org/materials/contrib/2006/Patrick_J_Fahy.pdf

Farahani, G. O. (2003). Existence and importance of online interaction. Dissertation submitted to the Faculty for the degree of Doctor of Philosophy, Virginia Polytechnic Institute and State University.

Garrison, R. D., \&Anderson, T. (2003). E-learning in the 21st century: A framework for research and practice. New York: Routledge Falmer.

J ulien, H., Robbins, J ., Logan, E., \& Dalrymple, P.(2006). Going the distance: Distance education in library and information science education. J ournal of Education for Library and Information Science, 42(3), 200-205.

Kearsley, G. (2001). Online education: Learning and teaching in cyberspace. New York: Wadsworth Publishing.

Kuh, G. D., \&Hu, S. (2001). The effects of student-faculty interaction in the 1990's. The Review of Higher Education, 24(3), 309-332.

Lulee, S.T. (2010). Basic principles of interaction for learning in web-based environment. Retrieved from http:// eddportfolio.susanlulee.com/ sites/default/files/Basic\%20Principles...

This work is licensed under a $\underline{\text { Creative Commons Attribution } 4.0 \text { International License. }}$ 
Moore, M. G., \& Kearsley, G. (2011) Distance education: A systems view of online learning.

Third Edition, Publisher: Linda Schreiber-Ganster. Retrieved from http://www.cengagebrain.com.mx/content/moore20992_1111520992_02.01_chapter01 .pdf

Parker, A. (2003). Identifying predictors of academic persistence in distance education. USDLA J ournal, 17(1), 55- 62.

Salmon, G. (2000). E-moderating: The key to teaching and learning online. London: Kogan.

Schillewaert, N., Langerak, F. \&Duhamel, T. (1998). non-probability sampling for WWW surveys: a comparison of methods. J ournal of the Market Research Society, 40(4), 307322.

Sing, C. C., \& Khine, M. S. (2006). An analysis of interaction and participation patterns in online community. Educational Technology \& Society, 9(1), 250-261.

Sutton, L. A. (2001). The principle of vicarious interaction in computer-mediated communications. International J ournal of Educational Telecommunications, 7(3), 223242 .

Svedberg, M. K. (2010). Self-directed learning and persistence in online asynchronous undergraduate programs. Dissertation for the Degree of Doctor of Philosophy, Virginia Polytechnic Institute and State University.

Tello, S.F. (2002). An analysis of the relationship between instructional interaction and student persistence in online education. Dissertation for the Degree of Doctor of Education, Massachusetts Lowell University.

Tinto, V. (1987). Leaving college: Rethinking the causes and cures of student attrition. Chicago: University of Chicago Press.

(C) Mahmodi and Ebrahimzade

\section{Athabasca University $\mathbf{Z}$}

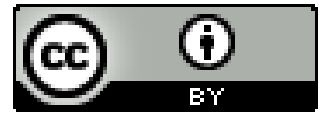

This work is licensed under a $\underline{\text { Creative Commons Attribution } 4.0 \text { International License. }}$ 